\title{
Bullera penniseticola sp. nov. and Kockovaella sacchari sp. nov., two new yeast species isolated from plants in Thailand
}

\author{
Masako Takashima and Takashi Nakase
}

Japan Collection of Microorganisms, The Institute of Physical and Chemical Research (RIKEN), Wako, Saitama 351-0198, Japan

\author{
Author for correspondence: Masako Takashima. Tel: +8148467 9560. Fax: +81484624617. \\ e-mail: masako@ulmus.riken.go.jp
}

\begin{abstract}
Two strains of ballistoconidium-forming yeasts, isolated from plants collected in the south-east seacoast of Bangkok, Thailand, were described. The strains (K-272' and K-337') were assigned to the genera Bullera and Kockovaella, respectively, based on morphological and chemotaxonomical characteristics. Phylogenetically, strain $\mathrm{K}-272^{\top}$ is close to Bullera hannae, and strain $\mathrm{K}-337^{\top}$ is close to Kockovaella thailandica and Kockovaella imperatae. These two strains represent new species based on DNA-DNA reassociation experiments. Bullera penniseticola Takashima et Nakase sp. nov. and Kockovaella sacchari Takashima et Nakase sp. nov. are proposed for K-272 ${ }^{\top}$ ( = JCM 9857') and K-337' ( = JCM 9858'), respectively.
\end{abstract}

Keywords: yeast, Bullera penniseticola sp. nov., Kockovaella sacchari sp. nov., Thailand

\section{INTRODUCTION}

In 1990, two ballistoconidium-forming yeasts, $\mathrm{K}-272^{\mathrm{T}}$ and $\mathrm{K}-337^{\mathrm{T}}$, were isolated from plant leaves collected in Thailand. Strain $\mathrm{K}-272^{\mathrm{T}}$, assigned to the genus Bullera, was characterized by coenzyme Q-10, the presence of xylose in the cells, and proliferation by ballistoconidia and budding cells. Strain K-337 ${ }^{\mathrm{T}}$, assigned to the genus Kockovaella, was characterized by Q-10 as major ubiquinone, the presence of xylose in the cells, and proliferation by stalked conidia, ballistoconidia and budding cells. Bullera sp. K-272 ${ }^{\mathrm{T}}$ showed physiological and biochemical characteristics similar to Bullera hannae, while Kockovaella sp. $\mathrm{K}-337^{\mathrm{T}}$ was found to be similar to Kockovaella thailandica and Kockovaella imperatae. DNA-DNA reassociation experiments, however, revealed that these yeasts represented new species of the genera Bullera and Kockovaella. They are described as Bullera penniseticola Takashima et Nakase sp. nov. and Kockovaella sacchari Takashima et Nakase sp. nov.

\section{METHODS}

Yeast strains. The strains $\mathrm{K}-272^{\mathrm{T}}$ and $\mathrm{K}-337^{\mathrm{T}}$ reported in this paper were isolated from leaves of Pennisetum sp. and

Abbreviation: SSU, small subunit.

The GenBank/EMBLDDBJ accession number for the sequences reported in this paper are AB005452 (Bullera penniseticola JCM 9857'), AB005453 (Kockovaella sacchari JCM 9858') and AB005561 (K. imperatae JCM 7826').
Saccharum officinarum, respectively, which were collected from the south-east seacoast of Bangkok, Thailand, using the ballistoconidium-fall method with YM agar (Difco) plates (Nakase \& Takashima, 1993).

Examination of morphological, physiological and biochemical characteristics. Most of the morphological, physiological and biochemical characteristics were examined according to the methods of van der Walt \& Yarrow (1984). Assimilation of nitrogen compounds was investigated on solid media using starved inocula according to the method of Nakase \& Suzuki (1986). Vitamin requirements were investigated according to the method of Komagata \& Nakase (1967). The maximum growth temperature was determined in YM broth (Difco) using metal block baths.

Ubiquinone system. Cells were grown in $500 \mathrm{ml}$ Erlenmeyer flasks containing $250 \mathrm{ml} \mathrm{YM}$ broth on a rotary shaker at 150 r.p.m. at $25^{\circ} \mathrm{C}$ and were harvested in the early stationary growth phase. The cells were washed with distilled water. Extraction, purification and identification of ubiquinones were carried out according to the method of Nakase \& Suzuki (1986).

Xylose in the cells. Cells were grown in $500 \mathrm{ml}$ Erlenmeyer flasks containing $250 \mathrm{ml} \mathrm{YM}$ broth on a rotary shaker at 150 r.p.m. at $25^{\circ} \mathrm{C}$ and were harvested in the early stationary growth phase. The cells were washed with distilled water and dried with acetone. Xylose in the cells was analysed as described by Suzuki \& Nakase (1988).

DNA base composition. Cells were grown in $500 \mathrm{ml}$ Erlenmeyer flasks containing $250 \mathrm{ml} \mathrm{YM}$ broth on a rotary shaker at 150 r.p.m. at $25^{\circ} \mathrm{C}$ and were harvested in the exponential growth phase. The cells were washed with distilled water and $0.067 \mathrm{M}$ phosphate buffer containing $1 \mathrm{mM}$ EDTA (pH 
7.4). Isolation and purification of DNA were carried out according to the methods of Nakase \& Suzuki (1986). The DNA base composition was determined by HPLC after enzymic digestion of DNA to deoxyribonucleosides. The DNA-GC Kit (Yamasa Shoyu) was used as a quantitative standard.

DNA-DNA relatedness. DNA-DNA reassociation experiments were carried out using a membrane-filter method according to the method of Hamamoto \& Nakase (1995).

Sequencing and phylogenetic analysis. The small subunit (SSU) rDNA sequence was determined after amplifying the gene using PCR. Both strands were sequenced by the dideoxy method as described by Takashima \& Nakase (1996). The SSU rDNA sequences of Bullera penniseticola JCM $9857^{\mathrm{T}}$ $\left(\mathrm{K}-272^{\mathrm{T}}\right)$, Kockovaella sacchari $\mathrm{JCM} 9858^{\mathrm{T}}\left(\mathrm{K}-337^{\mathrm{T}}\right)$ and $K$. imperatae JCM $7826^{\mathrm{T}}$ were determined in this study. Generated sequences were aligned with other unicellular and filamentous basidiomycetes using the CLUSTAL w computer program (Thompson et al., 1994). Sporidiobolus johnsonii and Sporobolomyces roseus were used as outgroups. The fixed gap and floating gap penalty values used in CLUSTAL were 10 . The alignment is available upon request. The phylogenetic tree was constructed from the evolutionary distance data according to Kimura (1980) using neighbourjoining method (Saitou \& Nei, 1987) in the CLUSTAL w computer program. Sites where gaps existed in any sequences were excluded. Bootstrap analyses (Felsenstein, 1985) were performed from 1000 random resamplings.

\section{RESULTS AND DISCUSSION}

\section{DNA base composition and DNA-DNA relatedness}

Fifteen species are now recognized in the genus Bullera. Suh \& Nakase (1995) and Suh et al. (1996) described the phylogenetic heterogeneity of the genus Bullera based on SSU rDNA sequences. The wide range of the DNA base composition, namely $39-62 \mathrm{~mol} \% \mathrm{G}+\mathrm{C}$, also predicts the heterogeneity of the genus.

The DNA base composition of Bullera sp. K-272 ${ }^{\mathrm{T}}$ was $44.2 \mathrm{~mol} \% \mathrm{G}+\mathrm{C}$, and similar to that of $B$. hannae and B. huiaensis (Hamamoto \& Nakase, 1996). In the neighbour-joining tree based on SSU rDNA sequences, however, Bullera sp. K-272 ${ }^{\mathrm{T}}$ showed close relationship (99.6\% sequence similarity) to $B$. hannae JCM 8937 and was located in a cluster different from that of $B$. huiaensis JCM 8933 (Fig. 1). DNA-DNA reassociation experiments, carried out between Bullera sp. $\mathrm{K}-272^{\mathrm{T}}$ and $B$. hannae, revealed DNA relatedness values of 23 and $26 \%$. This suggests that Bullera sp. K$272^{\mathrm{T}}$ is a species different from $B$. hannae.

Two species, $K$. thailandica and $K$. imperatae, have been described in the genus Kockovaella (Nakase et al. 1991). The DNA base composition of Kockovaella sp. $\mathrm{K}-337^{\mathrm{T}}$ was found to be $48.0 \mathrm{~mol} \% \mathrm{G}+\mathrm{C}$, and similar to those of the described species in the genus. As shown in Fig. 1, Kockovaella sp. K-337 ${ }^{\mathrm{T}}$ constituted a cluster with $K$. thailandica JCM $7824^{\mathrm{T}}$ and $K$. imperatae JCM $7826^{\mathrm{T}}$ in the neighbour-joining tree based on SSU rDNA sequences. DNA-DNA reassociation experiments carried out between Kockovaella sp. K-337,$K$. thailandica and $K$. imperatae showed low DNA relatedness values (5-15\%) (Table 1$)$.
Latin diagnosis of Bullera penniseticola Takashima et Nakase sp. nov.

In ' $Y M$ ', post dies 5 ad $25^{\circ} \mathrm{C}$, cellulae vegetativae ovoideae, ellipsoidales aut elongatae, $(2 \cdot 0-4 \cdot 0) \times(3 \cdot 3-$ 10.1) $\mu \mathrm{m}$, singulae aut binae. Sedimentum formatur. Post unum mensem ad $17^{\circ} \mathrm{C}$, annulus imperfectus, insulae et sedimentum formantur. In agaro ' $Y M$ ', post unum mensem ad $17^{\circ} \mathrm{C}$, cultura subflava, glabra, nitida, mollis et margine glabra. Mycelium et pseudomycelium non formantur. Ballistosporae globosae vel napiformes, $(2 \cdot 4-3 \cdot 5) \times(2 \cdot 6-4 \cdot 1) \mu \mathrm{m}$. Fermentatio nulla. Glucosum, galactosum, saccharosum, maltosum, cellobiosum, trehalosum, lactosum, melibiosum, raffinosum, melezitosum, amylum solubile, $D$-xylosum, L-arabinosum, $D$ arabinosum, D-ribosum, L-rhamnosum (lente), glycerolum (lente), ribitolum (lente et exiguum), galactitolum, D-mannitolum, D-glucitolum, methyl $\alpha$-D-glucosidum, salicinum (lente et exiguum), glucono- $\delta$-lactonum, acidum 2-ketogluconicum, acidum 5-ketogluconicum, acidum succinicum (exiguum), acidum citricum (exiguum) et inositolum assimilantur at non L-sorbosum, inulinum, ethanolum, erythritolum nec acidum DL-lacticum. Kalium nitricum, natrium nitrosum, ethylaminum, L- $^{-}$ lysinum et cadaverinum non assimilantur. Maxima temperatura crescentiae: $30-31^{\circ} \mathrm{C}$. Ad crescentiam thiaminum necessarium est. Diazonium caeruleum $B$ positivum. Proportio molaris guanini + cytosini in acido deoxyribonucleico: $44.2 \mathrm{~mol} \%$ (per HPLC). Ubiquinonum majus: Q-10. Xylosum in cellulis praesens. Holotypus: Isolatus ex folio Pennisetum species, JCM $9857^{\mathrm{T}}$ (originaliter ut $\mathrm{K}-272^{\mathrm{T}}$ ) conservatur in collectionibus culturarum quas 'Japan Collection of Microorganisms', Wako, Saitama sustentat.

\section{Description of Bullera penniseticola Takashima et Nakase sp. nov.}

In YM broth, after $5 \mathrm{~d}$ at $25^{\circ} \mathrm{C}$, the vegetative cells are ovoidal, ellipsoidal or elongate, $(2 \cdot 0-4 \cdot 0) \times(3 \cdot 3-10 \cdot 1)$ $\mu \mathrm{m}$, single or in pairs. A sediment is formed. After 1 month at $17^{\circ} \mathrm{C}$, an incomplete ring, islets and a sediment are present. On YM agar, after 1 month at $17^{\circ} \mathrm{C}$, the streak culture is pale yellow, shining, smooth and delicately wrinkled near the bottom, and has an entire margin. On Dalmau plate culture on corn meal agar, mycelia and pseudomycelia are not observed. Ballistoconidia are abundantly produced on corn meal agar. They are globose to napiform, $(2 \cdot 4-3 \cdot 5) \times$ $(2 \cdot 6-4 \cdot 1) \mu \mathrm{m}$ (Fig. 2). Does not ferment glucose. Assimilates glucose, galactose, sucrose, maltose, cellobiose, trehalose, lactose, melibiose, raffinose, melezitose, soluble starch, D-xylose, L-arabinose, D-arabinose, D-ribose, L-rhamnose (slow), glycerol (latent), ribitol (latent and weak), galactitol, D-mannitol, Dglucitol, methyl $\alpha$-D-glucoside, salicin (latent and weak), glucono- $\delta$-lactone, 2-ketogluconic acid, 5-ketogluconic acid, succinic acid (weak), citric acid (weak) and inositol. Does not assimilate L-sorbose, inulin, ethanol, erythritol or DL-lactic acid. Does not assimilate potassium nitrate, sodium nitrite, ethylamine hydrochloride, L-lysine hydrochloride, or cadaverine 


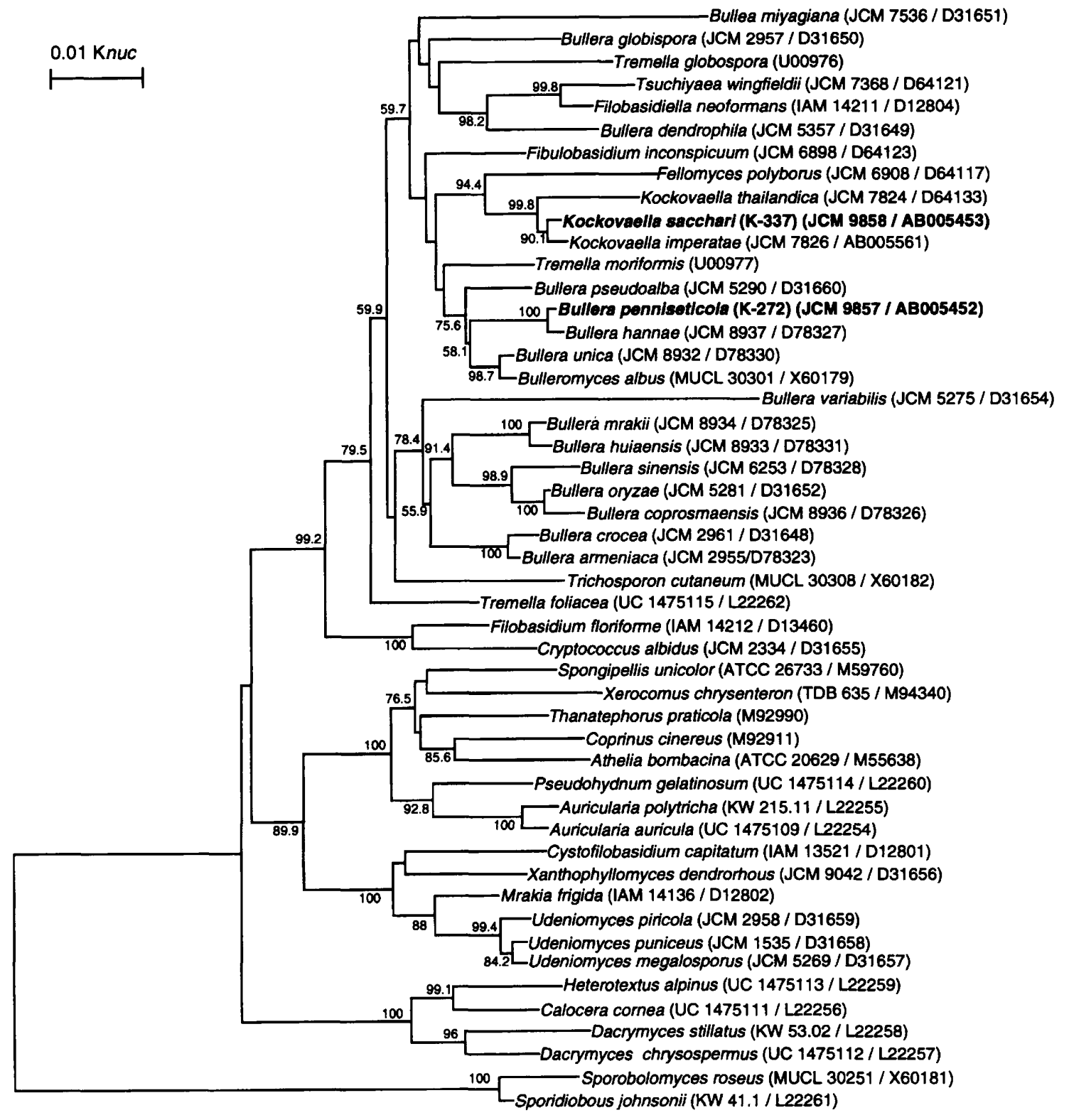

Fig. 1. Phylogenetic tree of Bullera, Kockovaella, Udeniomyces and related taxa based on SSU rDNA sequences. The tree was constructed from the evolutionary distance data according to Kimura (1980) using the neighbour-joining method (Saitou \& Nei, 1987) with bootstrapping (Felsenstein, 1985). The numerals represent the percentages from 1000 replicate bootstrap samplings. Sequences were retrieved from the DDBJ/EMBL/GenBank nucleotide sequence databases under the accession numbers indicated.

Table 1. DNA-DNA relatedness of Kockovaella sp. K-337' and other Kockovaella species

\begin{tabular}{|c|c|c|c|c|c|}
\hline \multirow[t]{2}{*}{ Species } & \multirow[t]{2}{*}{ Strain } & \multirow[t]{2}{*}{$\mathbf{G}+\mathbf{C}$ mol $\%$} & \multicolumn{3}{|c|}{$\begin{array}{l}\text { Percentage relative binding of DNA } \\
\text { from: }\end{array}$} \\
\hline & & & $\mathbf{K}-337^{\mathrm{T}}$ & $\mathrm{JCM} 7824^{\mathrm{T}}$ & $\mathrm{JCM} 7826^{\mathrm{r}}$ \\
\hline Kockovaella sp. & $\mathrm{K}-337^{\mathrm{T}}$ & $48 \cdot 0$ & 100 & 5 & 12 \\
\hline$K$. thailandica & $\mathrm{JCM} 7824^{\mathrm{T}}$ & $47 \cdot 5$ & 15 & 100 & 13 \\
\hline K. imperatae & $\mathrm{JCM} 7826^{\mathrm{T}}$ & $47 \cdot 7$ & 12 & 8 & 100 \\
\hline
\end{tabular}



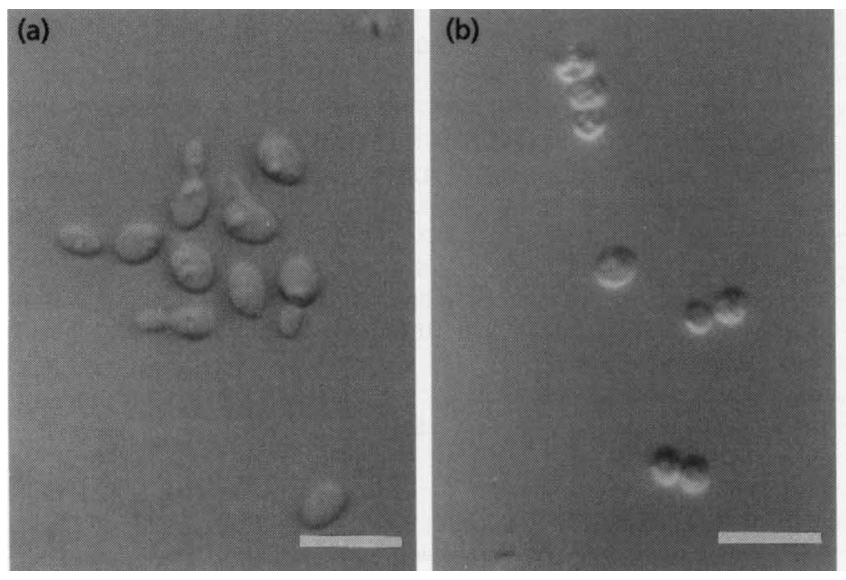

Fig. 2. Bullera penniseticola. (a) Vegetative cells grown in YM broth for $5 \mathrm{~d}$ at $25^{\circ} \mathrm{C}$. (b) Ballistospores produced on corn meal agar after $5 \mathrm{~d}$ at $25^{\circ} \mathrm{C}$. Bars, $10 \mu \mathrm{m}$.

dihydrochloride. Maximum growth temperature is $30-31{ }^{\circ} \mathrm{C}$. Thiamine is required for growth. No starchlike substances are produced. Growth does not occur on $50 \%(\mathrm{w} / \mathrm{w})$ glucose-yeast extract agar. Ureasepositive. Does not liquefy gelatin. Does not hydrolyse fat. The diazonium blue $B$ reaction is positive. The $\mathrm{G}+\mathrm{C}$ content of nuclear DNA is $44.2 \mathrm{~mol} \%$ as determined by HPLC. The major ubiquinone is Q- 10 . Xylose is present in the cells. The type strain of $B$. penniseticola, $\mathrm{K}-272^{\mathrm{T}}$, was isolated by $\mathrm{T}$. Nakase and B. Fungsin in December 1990 from a leaf of Pennisetum sp. collected along the south-east seacoast of Bangkok, Thailand. This strain has been deposited in Japan Collection of Microorganisms (JCM), Wako, Saitama, as JCM $9857^{\mathrm{T}}$. The physiological and biochemical characteristics of $B$. penniseticola are similar to those of $B$. hannae, but the maximum growth temperature, $30-31{ }^{\circ} \mathrm{C}$ for $B$. penniseticola and $22-$ $23^{\circ} \mathrm{C}$ for $B$. hannae, can clearly distinguish between these species.

\section{Latin diagnosis of Kockovaella sacchari Takashima et Nakase sp. nov.}

In liquido ' $Y M$ ', post dies 5 ad $25^{\circ} \mathrm{C}$, cellulae vegetativae sphaerical vel ovoideae, $(2 \cdot 0-6 \cdot 3) \times(3 \cdot 3-7 \cdot 3) \mu \mathrm{m}$, singulae, binae, in catenis aut in fasciculis, propagantes formatione conidiorum stipitatorum et gemmarum blasticarum. Conidia stipitata ex cellula conidiogena multilateraliter. Sedimentum formatur. Post unum mensem ad $17^{\circ} \mathrm{C}$, anulus, insulae et sedimentum formantur. In agaro ' $Y M$ ', post unum mensem ad $17^{\circ} \mathrm{C}$, cultura griseo-flava, glabra, nitida, butyracea et margine glabra. Mycelium et pseudomycelium non formantur. Ballistosporae globosae vel napiformes, $(2 \cdot 2-4 \cdot 0) \times(3 \cdot 1-4 \cdot 6)$ $\mu \mathrm{m}$. Fermentatio nulla. Glucosum, galactosum, saccharosum, maltosum, cellobiosum, trehalosum, lactosum, melibiosum, raffinosum, melezitosum, amylum solubile, $D$-xylosum, L-arabinosum, $D$-arabinosum (lente), $D$-ribo-

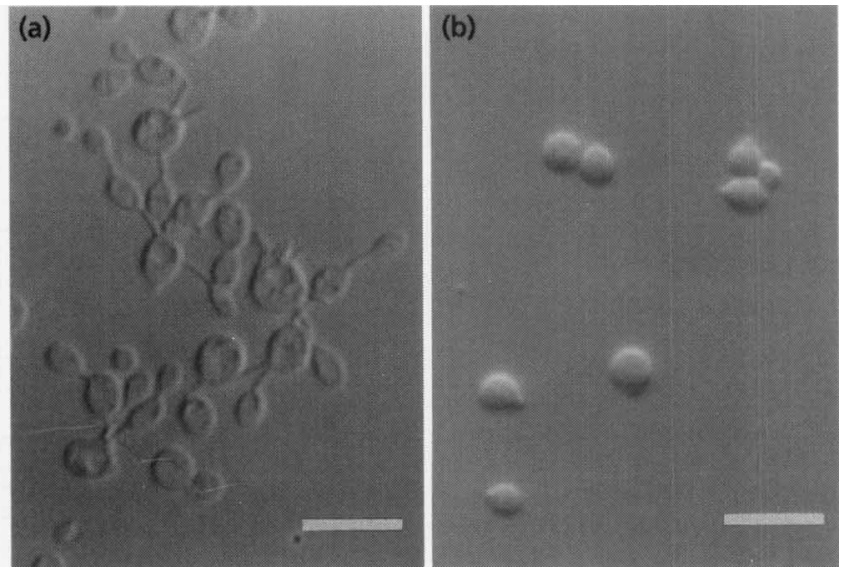

Fig. 3. Kockovaella sacchari. (a) Vegetative cells grown in YM broth for $5 \mathrm{~d}$ at $25^{\circ} \mathrm{C}$. (b) Ballistospores produced on corn meal agar after $5 \mathrm{~d}$ at $25^{\circ} \mathrm{C}$. Bars, $10 \mu \mathrm{m}$.

sum, L-rhamnosum (lente), ribitolum (lente), galactitolum (lente), D-mannitolum (lente), D-glucitolum (lente), methyl $\alpha$-D-glucosidum, salicinum, glucono- $\delta$ lactonum (exiguum), acidium succinicum (lente), acidum citricum (exiguum) et inositolum (lente et exiguum) assimilantur at non L-sorbosum, inulinum, ethanolum, glycerolum, erythritolum, acidum 2-ketogluconicum, acidum 5-ketogluconicum nec acidum DL-lacticum. L- $^{-}$ Lysinum assimilatur at non kalium nitricum, natrium nitrosum, ethylaminum nec cadaverinum. Maxima temperatura crescentiae: $31-32^{\circ} \mathrm{C}$. Ad crescentiam thiaminum necessarium est. Diazonium caeruleum B positivum. Proportio molaris guanini + cytosini in acido deoxyribonucleico: $48.0 \mathrm{~mol} \%$ (per HPLC). Ubiquinonum majus: Q-10. Xylosum in cellulis praesens. Holotypus: Isolatus ex folio Saccharum officinarum, JCM $9858^{\mathrm{T}}$ (originaliter ut $\mathrm{K}-337^{\mathrm{T}}$ ) conservatur in collectionibus culturarum quas 'Japan Collection of Microorganisms', Wako, Saitama sustentat.

\section{Description of Kockovaella sacchari Takashima et Nakase sp. nov.}

In YM broth, after $5 \mathrm{~d}$ at $25^{\circ} \mathrm{C}$, the vegetative cells are spherical to ovoidal $(2 \cdot 0-6 \cdot 3) \times(3 \cdot 3-7 \cdot 3) \mu \mathrm{m}$, single, in pairs or in clusters, reproduced by budding and stalked conidia. Stalks develop multilaterally from a conidiogenous cell. A sediment is formed. After 1 month at $17^{\circ} \mathrm{C}$, a complete ring and islets, and a sediment are present. On YM agar, after 1 month at $17^{\circ} \mathrm{C}$, the streak culture is greyish-yellow, shining, smooth, butyrous and has an entire margin. On Dalmau plate culture on corn meal agar, mycelia and pseudomycelia are not formed. Ballistoconidia are abundantly produced on corn meal agar. They are globose to napiform $(2 \cdot 2-4 \cdot 0) \times(3 \cdot 1-4 \cdot 6) \mu \mathrm{m}$ (Fig. 3). Does not ferment glucose. Assimilates glucose, galactose, sucrose, maltose, cellobiose, trehalose, lactose, melibiose, raffinose, melezitose, soluble starch, D-xylose, L-ar- 
Table 2. Salient characteristics of Kockovaella sacchari and other Kockovaella species

+ , Positive; L, latent; W, weak; LW, latent and weak; - , negative.

\begin{tabular}{|c|c|c|c|c|c|c|}
\hline \multirow[t]{2}{*}{ Species } & \multirow[t]{2}{*}{ Strain } & \multicolumn{5}{|c|}{ Assimilation of: } \\
\hline & & Galactitol & $\begin{array}{c}\text { Methyl } \\
\alpha \text {-D-glucoside }\end{array}$ & Glucono- $\delta$-lactone & $\begin{array}{c}\text { 2-Ketogluconic } \\
\text { acid }\end{array}$ & $\begin{array}{c}\text { 5-Ketogluconic } \\
\text { acid }\end{array}$ \\
\hline K. sacchari & JCM $9858^{\mathrm{T}}$ & $\mathbf{L}$ & + & W & - & - \\
\hline K. thailandica & JCM $7824^{\mathrm{T}}, \mathrm{JCM} 7825$ & - & $\mathrm{L} /-$ & - & + & + \\
\hline K. imperatae & $\mathrm{JCM} 7826^{\mathrm{T}}$ & $\mathrm{L}$ & - & $\mathrm{L}$ & LW & LW \\
\hline
\end{tabular}

abinose, D-arabinose (latent), D-ribose, L-rhamnose (latent), ribitol (latent), galactitol (latent), D-mannitol (latent), D-glucitol (latent), methyl $\alpha$-D-glucoside, salicin, glucono- $\delta$-lactone (weak), succinic acid (latent), citric acid (weak), and inositol (latent and weak). Does not assimilate L-sorbose, inulin, ethanol, glycerol, erythritol, 2-ketogluconic acid, 5-ketogluconic acid, or DL-lactic acid. Assimilates L-lysine hydrochloride. Does not assimilate potassium nitrate, sodium nitrite, ethylamine hydrochloride, or cadaverine dihydrochloride. Maximum growth temperature is $31-32^{\circ} \mathrm{C}$. Thiamine is required for growth. No starch-like substances are produced. Growth does not occur on $50 \%(\mathrm{w} / \mathrm{w})$ glucose-yeast extract agar. Urease positive. Does not liquefy gelatin. Does not hydrolyse fat. The diazonium blue $B$ reaction is positive. The $G+C$ content of nuclear DNA is $48.0 \mathrm{~mol} \%$ as determined by HPLC. The major ubiquinone is Q-10. Xylose is present in the cells. The type strain of $K$. sacchari, K$337^{\mathrm{T}}$, was isolated by T. Nakase and B. Fungsin in December 1990 from a leaf of Saccharum officinarum collected along the south-east seacoast of Bangkok, Thailand. This strain has been deposited in Japan Collection of Microorganisms, Wako, Saitama, as JCM $9858^{\mathrm{T}}$. Kockovaella sacchari is distinguished from $K$. thailandica by the assimilation of galactitol, 2ketogluconic acid, 5-ketogluconic acid, and from $K$. imperatae by the assimilation of methyl $\alpha$-D-glucoside (Table 2). This is the third species of the genus Kockovaella.

\section{ACKNOWLEDGEMENTS}

We thank Miss P. Atthasampunna and Mr B. Fungsin, Thailand Institute of Scientific and Technological Research, Bangkok, Thailand, for their help in collecting plant materials and the isolation of the strain reported in this paper. This study was supported in part by special coordination funds for promoting science and technology of the Science and Technology Agency of the Japanese Government.

\section{REFERENCES}

Felsenstein, J. (1985). Confidence limits on phylogenies: an approach using the bootstrap. Evolution 39, 783-791.
Hamamoto, M. \& Nakase, T. (1995). Ballistosporous yeasts found on the surface of plant materials collected in New Zealand. 1. Six new species in the genus Sporobolomyces. Antonie Leeuwenhoek 67, 151-171.

Hamamoto, M. \& Nakase, T. (1996). Ballistosporous yeasts found on the surface of plant materials collected in New Zealand. The genera Bensingtonia and Bullera with descriptions of five new species. Antonie Leeuwenhoek 69, 279-291.

Kimura, M. (1980). A simple method for estimating evolutionary rate of base substitutions through comparative studies of nucleotide sequences. J Mol Evol 16, 111-120.

Komagata, K. \& Nakase, T. (1967). Microbiological studies on frozen foods. V. General properties of yeasts isolated from frozen foods. J Food Hyg Soc Jpn 8, 53-57 (in Japanese).

Nakase, T. \& Suzuki, M. (1986). Bullera megalospora, a new species of yeast forming large ballistospores isolated from dead leaves of Oryza sativa, Miscanthus sinensis, and Sasa sp. in Japan. J Gen Appl Microbiol 32, 225-240.

Nakase, T. \& Takashima, M. (1993). A simple procedure for the high frequency isolation of new taxa of ballistosporous yeasts living on the surface of plants. RIKEN Rev 3, 33-34.

Nakase, T., Itoh, M., Takematsu, A., Mikata, K., Banno, I. \& Yamada, Y. (1991). Kockovaella, a new ballistospore-forming anamorphic yeast genus. J Gen Appl Microbiol 37, 175-197.

Saitou, N. \& Nei, M. (1987). The neighbor-joining method: a new method for reconstructing phylogenetic trees. Mol Biol Evol 4, 406-425.

Suh, S.-O. \& Nakase, T. (1995). Phylogenetic analysis of the ballistosporous anamorphic genera Udeniomyces and Bullera, and related basidiomycetous yeasts, based on 18S rDNA sequence. Microbiology 141, 901-906.

Suh, S.-O., Takashima, M., Hamamoto, M. \& Nakase, T. (1996). Molecular phylogeny of the ballistoconidium-forming anamorphic yeast genus Bullera and related taxa based on small subunit ribosomal DNA sequences. J Gen Appl Microbiol 42, 501-509.

Suzuki, M. \& Nakase, T. (1988). The distribution of xylose in the cells of ballistosporous yeasts - application of high performance liquid chromatography without derivatization to the analysis of xylose in whole cell hydrolysates. J Gen Appl Microbiol 34, 95-103.

Takashima, M. \& Nakase, T. (1996). A phylogenetic study of the genus Tilletiopsis, Tilletiaria anomala and related taxa based on the small subunit ribosomal DNA sequences. J Gen Appl Microbiol 42, 421-429. 
Thompson, J. D., Higgins, S. G. \& Gibson, T. J. (1994). CLUSTAL W: improving the sensitivity of progressive multiple sequence alignment through sequence weighting, position-specific gap penalties and weight matrix choice. Nucleic Acids Res 22, 4673-4680. van der Walt, J. P. \& Yarrow, D. (1984). Methods for the isolation, maintenance, classification and identification of yeasts. In The Yeasts: a Taxonomic Study, 3rd edn, pp. 45-105. Edited by N. J. W. Kreger-van Rij. Amsterdam: Elsevier. 